\title{
Impact of the soft-shell clam Mya arenaria on sulfate reduction in an intertidal sediment
}

\author{
Kim Hansen ${ }^{1, *}$, Gary M. King ${ }^{2}$, Erik Kristensen ${ }^{1}$ \\ ${ }^{1}$ Institute of Biology, Odense University, Campusvej 55, DK-5230 Odense M, Denmark \\ ${ }^{2}$ Darling Marine Center, University of Maine, Walpole, Maine 04573, USA
}

\begin{abstract}
Sulfate reduction and various parameters related to the sulfur cycle were examined at $\mathrm{mm}$ to $\mathrm{cm}$ scales around burrows of the soft-shell clam Mya arenaria in an intertidal sediment (Lowes Cove, Maine, USA). Sulfate reduction rates were 1.5 to 2 times higher in the inner 1 to $5 \mathrm{~mm}$ region surrounding the burrow than in ambient sediment. In contrast, pools of reduced sulfur increased with the distance from the burrow wall to values $\approx 1.5$ times higher in ambient sediment. The highest numbers of sulfate-reducing bacteria (estimated using a most-probable-number technique) and microbial biomass (estimated from phospholipid phosphorous content) relative to ambient sediment were found in the innermost zone around burrows. Results from an artificial burrow experiment showed that artificia] burrow irrigation suppressed sulfate reduction in the innermost zone around burrows, while radial profiles of reduced sulfur resembled those from $M$. arenaria burrows, indicating loss of reduced sulfur from the burrow wall. $M$. arenaria burrows are thus sites of enhanced microbial activity and a dynamic sulfur cycle, with turnover times of reduced sulfur compounds increasing with distance from the burrow wall. Enhanced sulfate reduction rates near burrows are likely caused by substrate enrichment, perhaps due to organic excretions from $M$. arenaria. The pattern of reduced sulfur turnover likely results from periodic oxygen inputs during burrow irrigation.
\end{abstract}

KEY WORDS: Bioturbation - Marine sediment Sulfate reduction Sulfate-reducing bacteria $\cdot$ Mya arenaria

\section{INTRODUCTION}

Benthic macrofauna profoundly affect the geochemistry and microbial processes of coastal sediments through feeding, burrowing and burrow ventilation (e.g Aller 1982, 1988, Andersen \& Kristensen 1988, 1991, Kristensen 1988). Sediment reworking buries fresh reactive organic matter from surface sediments to $\mathrm{cm}$ depths and exposes new surfaces for micrabial colonization (e.g. Rhoads 1974, Yingst \& Rhoads 1980). Burrow ventilation affects the exchange of solutes between sediment and overlying water, and is considered an important control of both aerobic and anaerobic microbial processes (Aller 1988, Kristensen 1988). The net result of macrofaunal activity is stimulated microbial growth and metabolism in the sedimentary

-E-mail: hansen@dou.dk environment. Accordingly, the burrows of infaunal macroinvertebrates are organic-rich sites of increased heterotrophic and chemolithotrophic activity (e.g Aller \& Yingst 1978, Kristensen et al. 1985, Aller \& Aller 1986, Reichardt 1988).

Sulfate reduction generally predominates terminal carbon oxidation in coastal marine sediments, typically accounting for about $50 \%$ of total mineralization, and about $90 \%$ of the anaerobic mineralization of organic matter (e.g. Sørensen et al. 1979, Jørgensen 1982, Jørgensen \& Sørensen 1985, Skyring 1987). However, despite the importance of sulfate reduction, relatively few studies have examined the role of benthic macrofauna on microbial processes related to the sulfur cycle. In a classic study, Aller \& Yingst (1978) demonstrated elevated rates of sulfate reduction in the burrow wall of the polychaete Amphitrite ornate, and proposed that increased mineralization rates due to burrowing infauna would mainly be caused by a stim- 
ulation of sulfate reduction in the sediment. Hines \& Jones (1985) showed that macrofaunal activity caused higher sulfate reduction rates relative to a non-bioturbated sediment, and argued that sulfate reduction was enhanced due to continual mixing of the sediment and redistribution of fresh reactive organic matter from surface sediment to depth in sediment. Similar effects on sulfate reduction have been reported by Goldhaber et al. (1977) and Berner \& Westrich (1985).

The soft-shell clam Mya arenaria L. occurs widely in the intertidal and subtidal zones of sub-boreal and boreal regions. This sessile, suspension-feeding bivalve is situated at 15 to $25 \mathrm{~cm}$ depth in the sediment, and accesses the surface by means of its fused inhalent and exhalent siphons. Previous studies have shown that populations of $M$. arenaria have important roles in benthic community metabolism and energy flow (Emerson et al. 1988). Filter-feeding activities of the clams also have a substantial role in transferring particulate material from the water column to the benthos (Nichols 1985). The impact of $M$. arenaria burrows on benthic nitrification has been investigated by Henriksen et al. (1983), who demonstrated increased potential nitrification rates in the oxidized zone surrounding the burrows compared to ambient sediment. More recently Pelegri \& Blackburn (1995) showed that both nitrification and denitrification are enhanced by $M$. arenaria.

The objective of the present study was to investigate the impact of Mya arenaria and its burrows on sulfate reduction and other aspects of the sulfur cycle in an intertidal sediment. Sulfate reduction was measured directly along radial profiles around $M$. arenaria burrows at $\mathrm{mm}$ intervals. The observations from $M$. arenaria burrows were compared with results from an experimental laboratory study using artificial burrows.

\section{MATERIALS AND METHODS}

Site description. Sediment used in this study was obtained from Lowes Cove, an intertidal mudflat on the Damariscotta River estuary in Maine, USA $\left(43^{\circ} 56^{\circ}\right.$ $\left.\mathrm{N}, 69^{\circ} 35^{\prime} \mathrm{W}\right)$. The cove is approximately $600 \mathrm{~m}$ long and 150 in wide and has an arca of about 5.9 ha. The mean tidal range is approximately $3 \mathrm{~m}$ and the salinity is constant around 28 to $30 \%$. Water temperature varies between a maximum of about $20^{\circ} \mathrm{C}$ in mid. August and a low around $0^{\circ} \mathrm{C}$ in mid-February. The sediments of Lowes Cove, which consist of fine silts and clays with an organic content of 2 to $5 \%$ dry wt, is highly bioturbated by macrobenthos. The most common macrofauna are the bivalve molluscs Macoma balthica, Mya arenaria and Mytilus edulis, littorinid gastropods Hydrobia spp., and a wide variety of poly- chaetes (e.g. Nereis succinea, Heteromastus filiformis, Scoloplos sp.). Various aspects of sediment chemistry and biology at this site have been described previously (e.g. Anderson et al. 1981, King et al. 1983, Rice 1986) A sampling site was chosen at the head of the cove where high densities of $M$. arenaria occur (up to 200 ind. $\mathrm{m}^{-2}$; Rice 1986). On an average high tide, water depth at this site is approximately 1 to $2 \mathrm{~m}$; the sediment is exposed for about 2 to $3 \mathrm{~h}$ during low tide.

Sampling. Sediments were collected at the onset of low tide when the mudflat was exposed. Sediment samples were obtained horizontally from Mya arenaria burrows after exposing a vertical profile of the sediment by digging with a 'clam fork'. During digging, the sediment typically cracked along burrow axes, exposing the burrow wall. A small undisturbed sediment sample was obtained by gently inserting a $5 \mathrm{~cm}^{3}$ 'cutoff' syringe 4 to $5 \mathrm{~cm}$ horizontally into the sediment (Fig. 1). Samples were obtained from burrows with a diameter of approximately 10 to $12 \mathrm{~mm}$, and were taken 5 to $6 \mathrm{~cm}$ below the sediment surface. To avoid interference from neighbouring burrows, only burrows with no adjacent openings within a distance of 8 to $10 \mathrm{~cm}$ were sampled. The syringes were sealed with butyl septa immediately after sampling and were returned to the laboratory for further processing (within $30 \mathrm{~min}$ after sampling). $M$. arenaria burrows were sampled on 2 occasions, in June and November

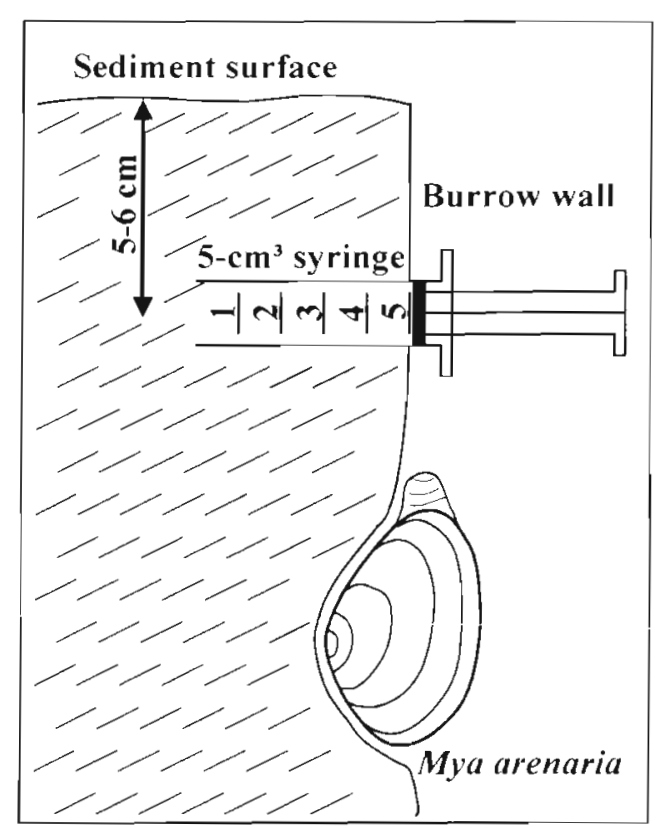

Fig. 1. Diagram showing the sampling procedure of horizontal sediment samples from Mya arenaria burrows. The burrow was exposed by digging with a 'clam fork' and a $5 \mathrm{~cm}^{3}$ 'cutoff.' syringe was carefully inserted horizontally into the sediment for sampling 
1994, respectively. Three additional sediment cores were collected in July 1994 with acrylic core liners (i.d. $2.9 \mathrm{~cm}$ ) for the determination of vertical profiles of sulfate reduction in the upper $10 \mathrm{~cm}$ sediment. Samples were obtained at the same location as the 'Mya samples', but care was taken to avoid coring close to $M$. arenaria burrows. In situ water temperature ranged between 14 and $18^{\circ} \mathrm{C}$. In the summer period, however, temperatures in the upper exposed sediment layer likely increased significantly during low tide due to high solar illumination.

Sulfate reduction. Radial profiles of sulfate reduction were made from syringe-collected sediment at $\mathrm{mm}$ intervals from the burrow wall and $25 \mathrm{~mm}$ into the ambient sediment, using a modified version of the ${ }^{35} \mathrm{~S}$ $\mathrm{SO}_{4}{ }^{2-}$ injection technique (Jørgensen 1978a). Sulfate reduction was determined in 9 burrow samples. To each syringe was injected $10 \mu l$ of carrier-free ${ }^{35} \mathrm{~S}$ $\mathrm{SO}_{4}{ }^{2-}(\approx 600 \mathrm{kBq})$ through the septum along the centra] axis using a Hamilton syringe that was slowly withdrawn through the sediment sample as the radiotracer was injected, thus ensuring as even a distribution of ${ }^{35} \mathrm{~S}_{-} \mathrm{SO}_{4}{ }^{2-}$ as possible. Samples were incubated in the dark for 4 to $5 \mathrm{~h}$ at $18^{\circ} \mathrm{C}$. Incubations were terminated by freezing in $-80^{\circ} \mathrm{C}$ ethanol, and samples were stored frozen until further treatment. Sediment cores for vertical profiles of sulfate reduction were injected with $4 \mu$ carrier-free ${ }^{35} \mathrm{~S}_{-} \mathrm{SO}_{4}{ }^{2-}(\approx 200 \mathrm{kBq})$ through each of 10 silicone-filled injection ports ( $1 \mathrm{~cm}$ apart) along the core liner. Sediment cores were incubated in darkness for $5 \mathrm{~h}$ at $18^{\circ} \mathrm{C}$, and incubations were terminated as described above.

The radial burrow samples were extruded stepwise while still frozen, and cut in millimeter sections: $1 \mathrm{~mm}$ intervals to $4 \mathrm{~mm}$ depth, $2 \mathrm{~mm}$ intervals to $10 \mathrm{~mm}$ depth, followed by $5 \mathrm{~mm}$ intervals to $25 \mathrm{~mm}$ depth (the direction from the interface of the burrow wall and horizontally into the ambient sediment is here designated as depth). Each sediment portion was immediately transferred to a pre-weighed $15 \mathrm{ml}$ centrifuge tube containing $5 \mathrm{ml}$ of $5 \% \mathrm{ZnAc}$; the tube and sediment was then re-weighed. The vertical $2.9 \mathrm{~cm}$ i.d. sediment cores were sectioned into $0.5 \mathrm{~cm}$ segments for the upper $2 \mathrm{~cm}$, and into $1 \mathrm{~cm}$ segments for the 2 to $10 \mathrm{~cm}$ depth section. About $1 \mathrm{~g}$ of sediment from each section was fixed with $8 \mathrm{ml}$ of $5 \% \mathrm{ZnAc}$ in centrifuge tubes. The tubes were shaken vigorously, and centrifuged at $3000 \mathrm{rpm}(1200 \times \mathrm{g})$ for $5 \mathrm{~min}$. Of the supernatant, $100 \mu \mathrm{l}$ was assayed for ${ }^{35} \mathrm{~S}_{-} \mathrm{SO}_{4}{ }^{2-}$, and 1.5 to $4.0 \mathrm{ml}$ were used for turbidometrically determination of total sulfate concentration (Tabatabai 1974). The sediment was transferred quantitatively into a $100 \mathrm{ml}$ reaction flask with $8 \mathrm{ml}$ of $50 \%$ ethanol. Radiolabeled sulfide and total reduced inorganic sulfur (TRS) were recovered by a single-step distillation procedure (King et al, 1985, Fossing \& Jørgensen 1989). After sparging for 10 to $15 \mathrm{~min}$ with a stream of nitrogen, $15 \mathrm{ml}$ of $1 \mathrm{M}$ $\mathrm{CrCl}_{2}$ in $1 \mathrm{M} \mathrm{HCl}$ was added. Sulfide liberated by a $60 \mathrm{~min}$ boiling distillation was trapped as $\mathrm{ZnS}$ in $6 \mathrm{ml}$ of $5 \%$ ZnAc. Aliquots (50 to $500 \mu \mathrm{l}$ ) of the traps were subsampled for sulfide analysis (TRS) using the methylene blue technique of Cline (1969). Radioactivity in the supernatant $\left({ }^{35} \mathrm{~S}-\mathrm{SO}_{4}{ }^{2-}\right)$ and the traps $\left({ }^{35} \mathrm{~S}-\sum \mathrm{H}_{2} \mathrm{~S}\right)$ were determined in a LKB 1218 scintillation counter (LKB, Pharmacia, Inc., Gaithersburg, MD, USA).

Solid phase iron. Sediment samples for radial profiles of solid phase iron were obtained from Mya arenaria burrows in the same intervals as described for the sulfate reduction assay. Solid phase iron was determined by $\mathrm{HCl}$ - and hydroxylamine-extractions using a method modified from Lovley \& Phillips (1987). Briefly, a $100 \mathrm{mg}$ subsample of homogenized sediment from each section was quickly transferred into $5 \mathrm{ml}$ of $0.25 \mathrm{M} \mathrm{HCl}[\mathrm{HCl}$-extractable Fe(II)]. A similar subsample was transferred into $5 \mathrm{ml}$ of $0.25 \mathrm{M}$ hydroxylamine hydrochloride in $0.25 \mathrm{M} \mathrm{HCl}$ ( $\mathrm{HCl}$-extractable total $\mathrm{Fe}$ ). Both mixtures were shaken at regular intervals for $1 \mathrm{~h}$ at room temperature. Following centrifugation $(1200 \times g, 5 \mathrm{~min}), 50 \mu \mathrm{l}$ of the supernatant was diluted to $5 \mathrm{ml}$. Then $0.1 \mathrm{ml}$ of $5 \mathrm{M} \mathrm{HCl}, 0.25 \mathrm{ml}$ Ferrozine solution $\left(0.075 \% \mathrm{w} / \mathrm{v}\right.$ in $\left.1 \mathrm{mM} \mathrm{H}_{2} \mathrm{SO}_{4}\right)$ and $0.625 \mathrm{ml}$ acetate buffer were added and the resulting solution (final $\mathrm{pH}$ $\approx 4.5$ ) mixed well. The samples were allowed to stand for $15 \mathrm{~min}$ for color development before the absorbance was read at $562 \mathrm{~nm}$. The amount of hydroxylamine-reducible Fe(III) was estimated as the difference between Fe(II) measured in the hydroxylamine and the $\mathrm{HCl}$ extraction (Lovley \& Phillips 1987).

Sulfate-reducing bacteria (MPN assay). Sulfatereducing bacteria were enumerated by the mostprobable-number (MPN) technique (American Public Health Association 1969). Anoxic defined mineral medium was prepared as described by Widdel \& Bak (1991), using a trace element solution described by Widdel (1986). A filter-sterilized vitamin solution (Widdel \& Pfennig 1981) was added after autoclaving the medium. The $\mathrm{pH}$ was adjusted to 7.2 , and the medium was dispensed into $100 \mathrm{ml}$ airtight screw-cap bottles. The electron donors formate and acetate were added from concentrated sterile stock solutions before inoculation (final concentration $3 \mathrm{mM}$ acetate and $12 \mathrm{mM}$ formate). The medium was dispensed in $9 \mathrm{ml}$ portions into $15 \mathrm{ml}$ tubes and gassed immediately with $\mathrm{N}_{2}-\mathrm{CO}_{2}$ $(87: 13 \mathrm{vol} / \mathrm{vol})$. Tubes were sealed with butyl stoppers. Substrate-free medium were inoculated with wall sediment (1-3 $\mathrm{mm}$ ) and ambient sediment (25-30 $\mathrm{mm}$ ) from Mya arenaria burrows (1:10 dilution). Sediment from 8 individual burrows was pooled. The inoculum was vigorously homogenized, and $1 \mathrm{ml}$ was transferred to the first tube in each dilution series (Bak \& Pfenning 
1.991) and gently mixed and gassed with $\mathrm{N}_{2}-\mathrm{CO}_{2}$. The dilution procedure was repeated serially to yield a final dilution of $10^{-8}$ An electron donor-free dilution series served as control. Three parallel dilution series were made for each treatment type. The tubes were incubated at $30^{\circ} \mathrm{C}$ in the dark. After $12 \mathrm{wk}$ tubes were analyzed for sulfide production with $\mathrm{CuSO}_{4}-\mathrm{HCl}$ reagent (Cord-Ruwisch 1985), and the MPN of sulfatereducing bacteria estimated from statistical tables (American Public Health Association 1969).

Microbial biomass. The content of phospholipids was measured as phospholipid phosphorus according to Findlay et al. (1989) and Dobbs \& Findlay (1993), and used as an estimate of total microbial biomass in burrow wall (1-3 $\mathrm{mm}$ ) and ambient (25-30 mm) sediment. Sediment samples from several Mya arenaria burrows were obtained as previously described and pooled to obtain an appropriate mass. Briefly, lipids were recovered from $1 \mathrm{~cm}^{3}$ sediment samples by extraction in a dichloromethane-methanol mixture. Phospholipid phosphate was liberated by potassium persulfate digestion of the extract, and measured colorimetrically (Findlay et al. 1989). The concentration of phosphorus was calculated using a standard curve prepared by digesting parallel samples with known concentrations of glycerol phosphate.

Sediment characteristics. Additional samples from Mya arenaria burrows were taken to determine sediment characteristics. Density was obtained from the wet weight of a known sediment volume. Water content was determined by drying sediment samples at $110^{\circ} \mathrm{C}$ for $12 \mathrm{~h}$. Organic content was measured on dried sediment samples as loss-on-ignition (LOI) at $520^{\circ} \mathrm{C}$ for $6 \mathrm{~h}$, and as particulate organic carbon (POC) and nitrogen (PON) using a Carlo Erba EA1108 Ele- mental Analyzer according to the procedure of Kristensen \& Andersen (1987).

Artificial burrow experiment (ABEX). The effect of burrow irrigation on sulfate reduction and pools of reduced sulfur was assessed in an experimental study using artificial burrows in laboratory microcosms. The ABEX design provided a well-suited tool for examining the impact of burrow irrigation, because all other influences associated with burrow-dwelling animals, such as mucus secretions, were eliminated. For simplicity, the artificial burrow was not designed to mimic a Mya arenaria burrow, but rather to model a simple cylinder-shaped 'standard burrow'

Surface sediment $(0$ to $8 \mathrm{~cm}$ depth) was sieved through a $1.0 \mathrm{~mm}$ mesh to remove macrofauna and larger particles (e.g. shell debris, gravel etc.). The sediment was allowed to settle for $3 \mathrm{~d}$ and was homogenized before it was transferred into acrylic core liners $(20 \mathrm{~cm}$ long, $7.6 \mathrm{~cm}$ i.d.) to a depth of about $13 \mathrm{~cm}$. Each core was equipped with four $14 \mathrm{~mm}$ i.d. sampling ports placed pairwise at 4 and $8 \mathrm{~cm}$ depth below the sediment surface (Fig. 2). Sampling ports were plugged tightly with rubber stoppers before the sediment was added. The sediment cores were placed in a darkened seawater tank (180 l) supplied with running oxic seawater (temperature 15 to $17^{\circ} \mathrm{C}$ ). The sediment was allowed to equilibrate for $3 \mathrm{wk}$ before introduction of the artificial burrows.

Artificial burrows (Fig. 2) were constructed using polyethylene filtration screens (Spectra/Mesh; mesh size $114 \mu \mathrm{m})$. A rectangular $(12 \times 3 \mathrm{~cm})$ sheet was fused into a cylinder-shaped burrow (i.d. $8 \mathrm{~mm}$ ) using a 'Tefal Jet Line $30^{\prime}$ iron and sealed at the bottom with the cutoff tip of a microcentrifuge tube. The burrow was mounted on a glass rod and carefully inserted vertically

\section{Artificial burrow experiment}

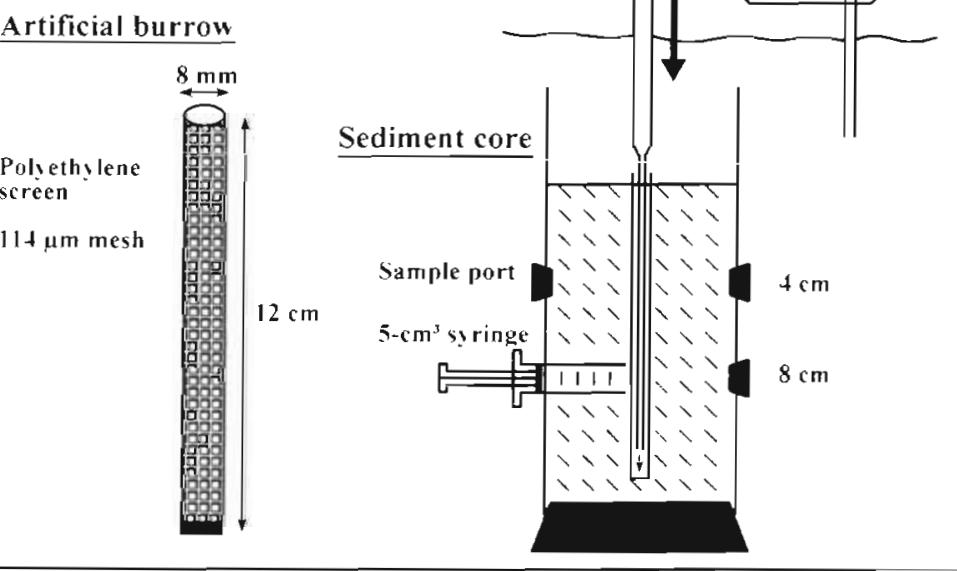

Fig. 2. Experimental design of the artificial burrow experiment (ABEX). An artificial burrow, constructed of polyethylene filtration screen (mesh size $114 \mu \mathrm{m}$ ) was inserted vertically into a sediment core (i.d. $7.6 \mathrm{~cm}$, sediment height $13 \mathrm{~cm}$. Fresh seawater was passed through a Pasteur pipette to the bottom of the burrow via a peristaltic pump. Horizontal sediment samples were obtained by removing a sample port plug and inserting a $5 \mathrm{~cm}^{3}$ 'cutoff' syringe towards the core center 
into the center of the sediment core; the glass rod was subsequently pulled out. Seawater was passed through a Pasteur pipette to the bottom of the burrow at a constant flow rate of $100 \mathrm{ml} \mathrm{h}^{-1}$, using a peristaltic pump. This was considerably lower than previously reported pumping rates of Mya arenaria $\left(0.7\right.$ to $3.0 \mathrm{l} \mathrm{h}^{-1} \mathrm{~g}^{-1} \mathrm{dry}$ tissue wt; Jørgensen \& Riisgård 1988), but within the range of ventilation rates recorded for a number of other infaunal burrow dwellers (e.g. Foster-Smith 1978, Kristensen 1988). One artificial burrow was established in each of 4 sediment cores, and another 4 sediment cores with no burrows served as controls

Sulfate reduction rates were measured after operating the cores for $6 \mathrm{wk}$ after introduction of artificial burrows. The sediment cores were removed from the tank and the overlying water siphoned off. A glass rod was carefully mounted in the burrow before sampling to stabilize the burrow and diminish disturbance. Sediment subsamples were obtained by removing the sample port plugs and carefully inserting a $5 \mathrm{~cm}^{3}$ 'cutoff' syringe horizontally in to each sample port towards the core center. Sampling from 2 parallel ports was done synchronously; care was taken to insert the syringe all the way to the artificial burrow to obtain the sediment adjacent to the artificial burrow wall. Sampling was conducted from top to bottom, starting with the $4 \mathrm{~cm}$ depth samples. Sampling of control cores (no burrows) was accomplished similarly, but without insertion of a glass rod. The syringe cores were immediately sealed with butyl septa, and each was injected with $10 \mu \mathrm{l}$ of carrier-free ${ }^{35} \mathrm{~S}-\mathrm{SO}_{4}{ }^{2-}(\approx 600 \mathrm{kBq})$ within 10 min after sampling. Incubation, sediment sectioning and analysis of sulfate reduction were conducted as described previously for the Mya arenaria burrow samples. Samples from control cores, however, were sectioned in $5 \mathrm{~mm}$ intervals.

\section{RESULTS}

\section{Sediment cores}

General observations

Sediment cores collected for measurements of vertical profiles of sulfate reduction had a brownish oxidized zone in the upper 2 to $3 \mathrm{~cm}$. Below this depth, the reduced sediment was greyish-black. Visually the sediment appeared heterogeneous with an irregular transition between oxidized and reduced sediment. Faunal activity (other than Mya arenaria) in the sediment was evident as local extensions of the oxidized zone into the otherwise reduced sediment. Benthic microalgae were abundant on the sediment surface, whereas macroalgae (e.g. Enteromorpha sp., Chaetomorpha sp.) were more scattered in occurrence.

\section{Sulfate reduction and reduced inorganic sulfur}

Considerable variability was observed in vertical profiles of sulfate reduction rates (SRR) and TRS among 3 replicate sediment cores, as evidenced by relatively large standard deviations particularly near the sediment surface (Fig. 3). Rates of sulfate reduction (Fig. 3A) increased rapidly with depth from about 125 to $350 \mathrm{nmol}$ $\mathrm{cm}^{-3} \mathrm{~d}^{-1}$ in the upper $0-1.5 \mathrm{~cm}$ interval. Maximum average rates close to $350 \mathrm{nmol} \mathrm{cm} \mathrm{cm}^{-3} \mathrm{~d}^{-1}$ occurred in the $1.5-3 \mathrm{~cm}$ depth interval. Below $3 \mathrm{~cm}$, SRR gradually declined with depth, reaching a level in the 9 to $10 \mathrm{~cm}$ interval ( $110 \mathrm{nmol} \mathrm{cm} \mathrm{cm}^{-3} \mathrm{~d}^{-1}$ ) similar to the rate observed in the uppermost sediment layer $(0-0.5 \mathrm{~cm})$.

TRS concentrations (Fig. 3B) increased gradually with depth from about $43 \mu \mathrm{mol} \mathrm{S} \mathrm{cm}^{-3}$ in the upper
Fig. 3. Vertical distribution of (A) sulfate reduction rates (SRR) and (B) total reduced inorganic sulfur (TRS). Values presented as mean $\left( \pm \mathrm{SE}_{i} \mathrm{n}=3\right)$
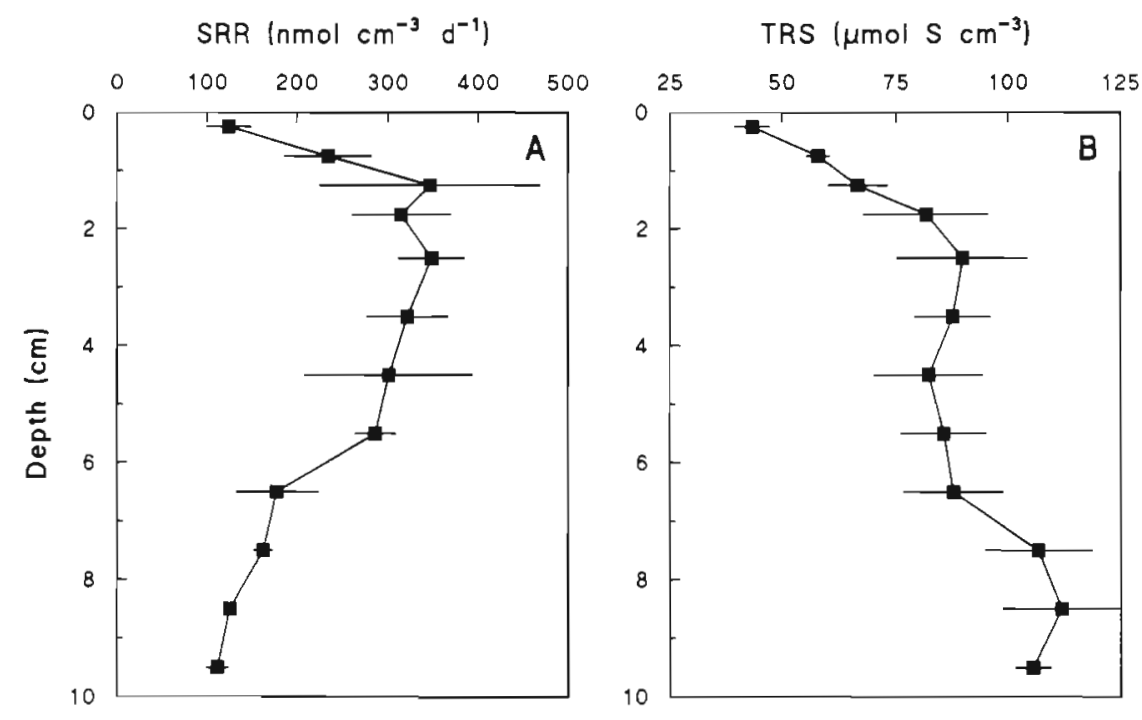
$0.5 \mathrm{~cm}$ to about 85 to $90 \mu \mathrm{mol} \mathrm{S} \mathrm{cm}{ }^{-3}$ in the $2-3 \mathrm{~cm}$ interval. Concentrations between about 2 to $7 \mathrm{~cm}$ depth were more or less constant, but were followed by an increase, reaching maximum values (105 to $110 \mu \mathrm{mol} \mathrm{S} \mathrm{cm}^{-3}$ ) in the lower 7 to $10 \mathrm{~cm}$

\section{Mya arenaria burrows}

\section{General observations}

Visual observations during sampling showed that Mya arenaria burrows were surrounded by a 2 to $5 \mathrm{~mm}$ thick oxidized zone. The thickness of this zone varied considerably between individual burrows, but decreased only slightly with depth in each individual burrow. The clams were typically positioned at 12 to $20 \mathrm{~cm}$ depth, and only a thin oxidized sediment zone (about 0.5 to $1 \mathrm{~mm}$ ) was evident around the shells of the animals.

\section{Sediment characteristics}

The presence of Mya arenaria burrows affected the sediment water content, which was about $24 \%$ higher in sediment immediately surrounding the burrow compared to the ambient sediment (20-25 mm depth) (data not shown). The organic content (Fig. 4A \& B) was relatively high in the inner $1-3 \mathrm{~mm}$ region surrounding the burrow (1.05 to $1.13 \%$ POC and 0.10 to $0.11 \%$ PON), and decreased gradually by 10 to $15 \%$ with distance from the burrow wall. The corresponding molar $C: N$ ratio (Fig. $4 \mathrm{C}$ ) was relatively low in the inner 1-3 mm region (11.6 to 11.9) and increased considerably in the succeeding 2 intervals (12.9 to 13.2). In ambient sediment $(>6 \mathrm{~mm})$, the $\mathrm{C}: \mathrm{N}$ ratio ranged from 12.2 to 12.8 .

\section{Sulfate reduction and reduced inorganic sulfur}

Radial profiles of SRR in sediment around Mya arenaria burrows varied both with distance from the wall and between individual burrows (Fig 5). In general. 2 basic types of profiles were observed. In one type (Type I; Fig. 5A-E), the highest rates were found in the inner $0-5 \mathrm{~mm}$ radial region followed by a gradual decline with distance, reaching a relatively constant level in the ambient (>10 mm) sediment. Maximum rates measured in the burrow wall of Type I were typically 2 to 2.5 times higher than rates in the ambient sediment, but the absolute magnitude of SRR differed markedly from burrow to burrow (e.g Fig. 5A-D) In the other type (Type $I_{i}$ Fig $5 \mathrm{~F}-\mathrm{I}$ ), maximum rates
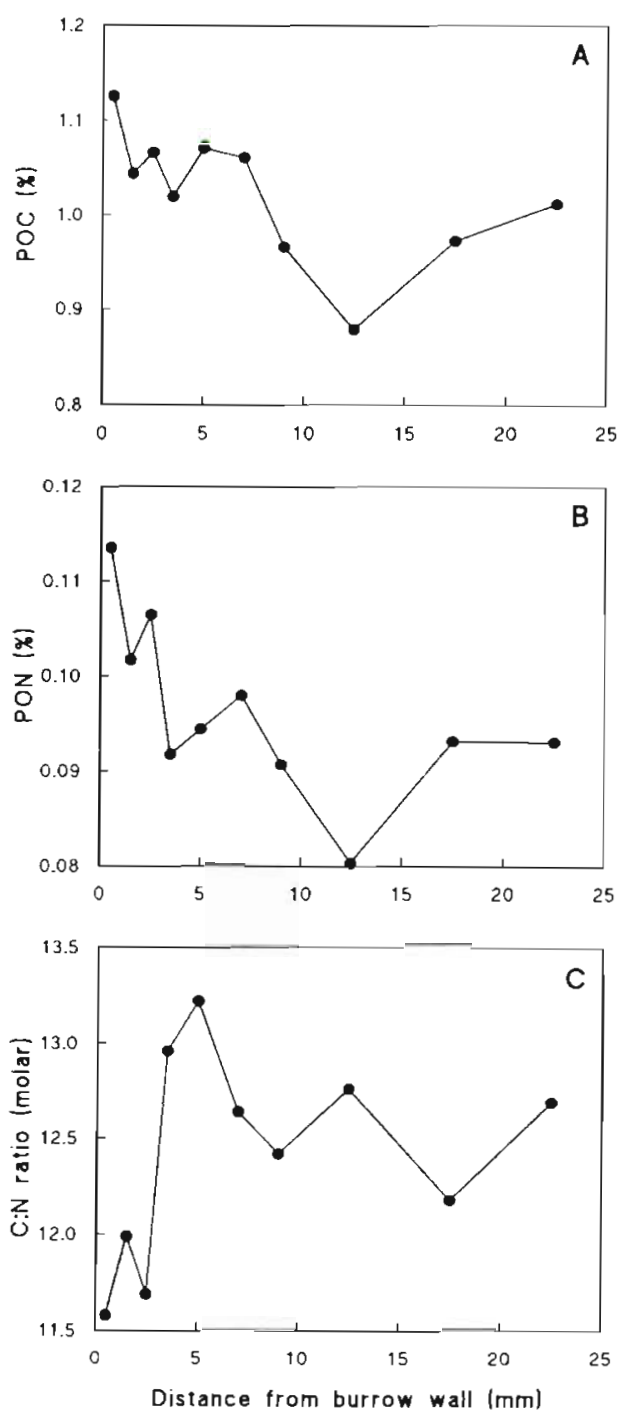

Fig. 4. Radial profiles of (A) particulate organic carbon (POC), (B) particulate organic nitrogen (PON) and (C) POC:PON ratio (molar) in sediment surrounding burrows of Mya arenaria. Values represent single determinations of sediment pooled from 4 burrows. Values given as $\%$ dry sediment weight

were observed in the 4-10 $\mathrm{mm}$ interval; the maxima were about 2 -fold higher than rates in the $1-4$ and 10-30 mm intervals. Of the total burrow samples, about half were characterized as Type I. There was no relation between types of profiles and the time of sampling (June and November).

The radial profiles of TRS varied considerably among samples and within profiles (Fig. 6). TRS concentrations generally increased with distance from the burrow wall, although some profiles were erratic and irregular (e.g. Fig. 6B, C \& I) with more or less constant levels among depth intervals. There was no general relationship between SRR and the corresponding TRS concen- 

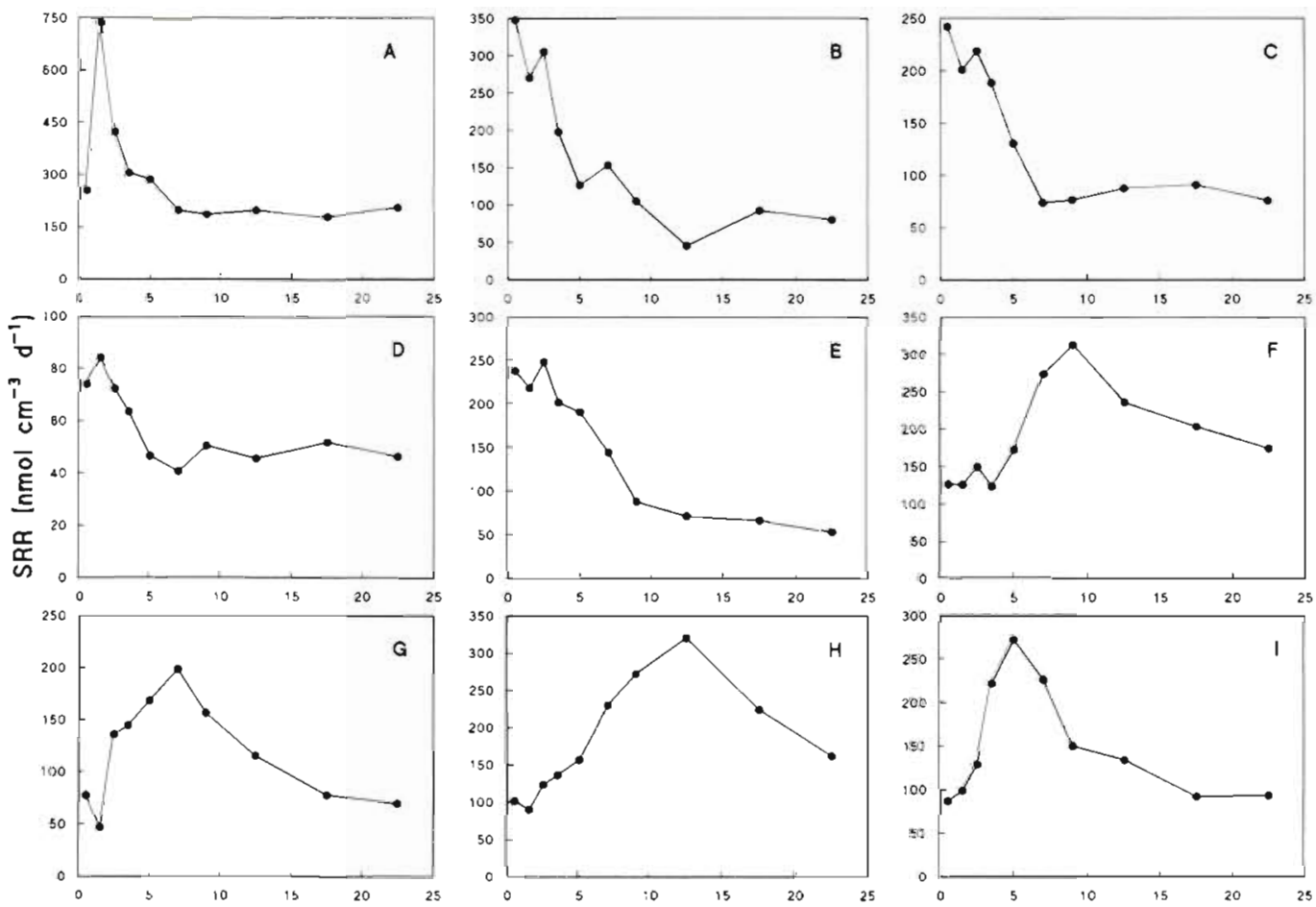

Distance from burrow wall $(\mathrm{mm})$

Fig. 5. Radial burrow profiles of sulfate reduction rates (SRR) in sediment surrounding Mya arenaria burrows. Each profile represents 1 individual burrow sample obtained from 5 to $6 \mathrm{~cm}$ depth. Values are single determinations of each radial depth. $(D-F)$ represent burrows sampled in November; the remaining burrows were sampled in June. Note different scaling
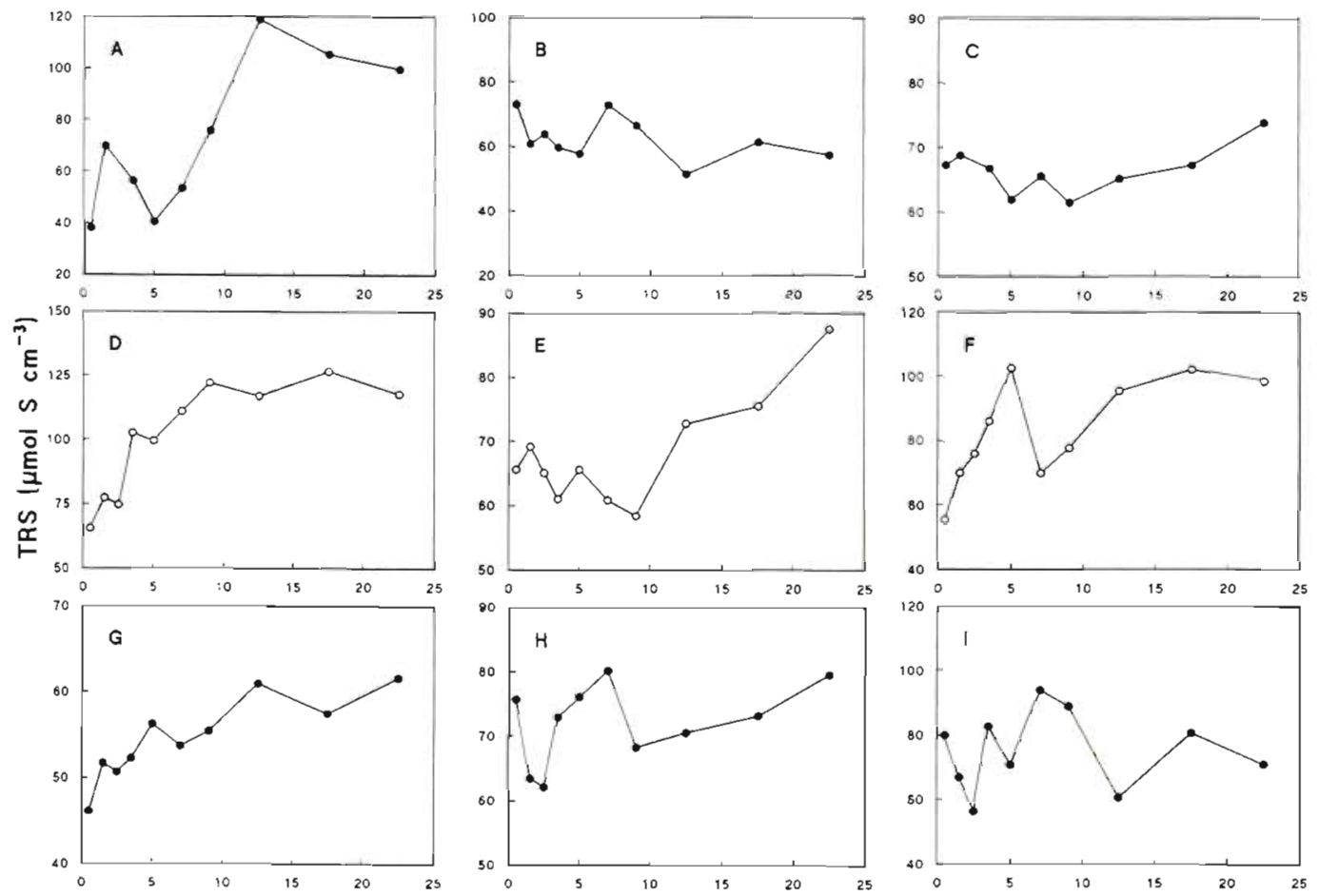

Distance from burrow wall $(\mathrm{mm})$

Fig. 6. Radial burrow profiles of total reduced inorganic sulfur (TRS) in sediment surrounding Mya arenaria burrows. Each profile represents 1 individual burrow sample obtained from 5 to $6 \mathrm{~cm}$ depth. Profiles are equivalent to those in Fig. 5 except for (D-F) (o) which represent samples without corresponding SRR data. Note different scaling 

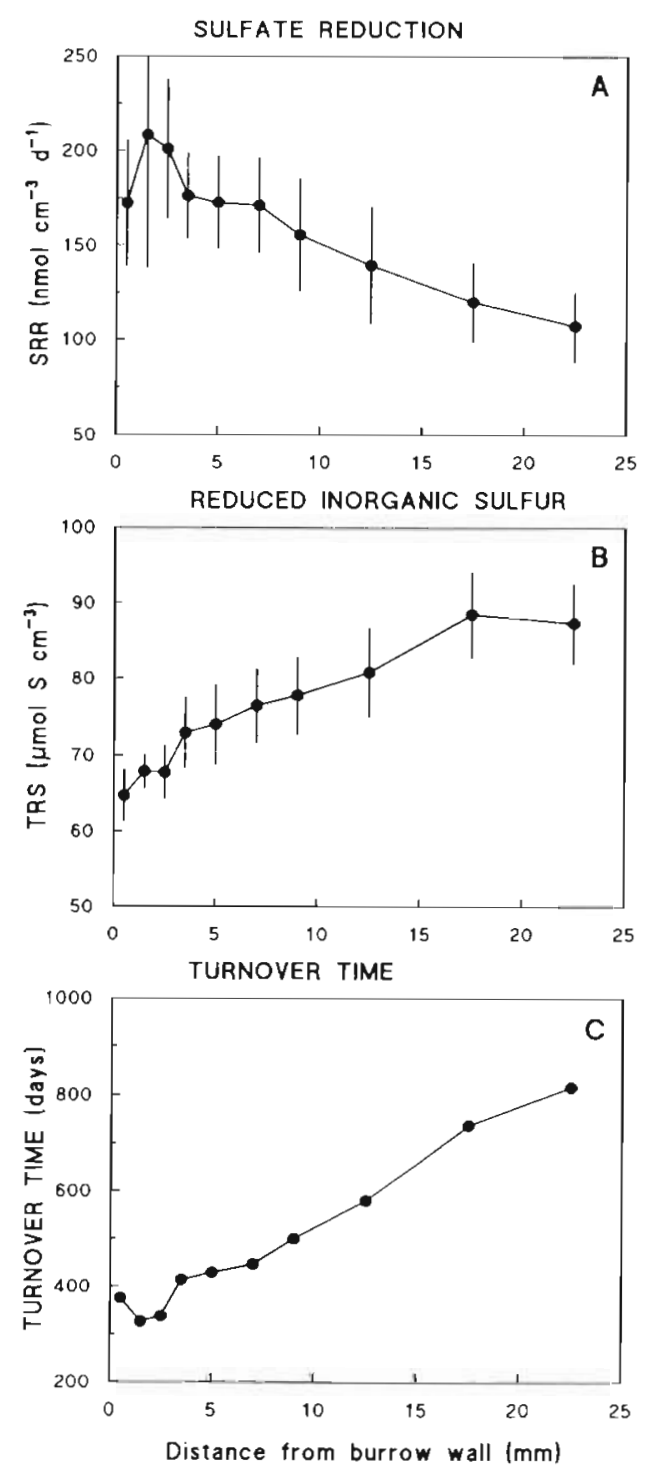

Fig. 7. Radial profiles of (A) sulfate reduction rates (SRR), (B) total reduced inorganic sulfur (TRS) and (C) turnover time of reduced sulfides, in sediment surrounding Mya arenaria burrows. Values are mean $\left( \pm \mathrm{SE}_{\mathrm{i}} \mathrm{n}=9\right)$ of profiles presented in Figs. $5 \& 6$

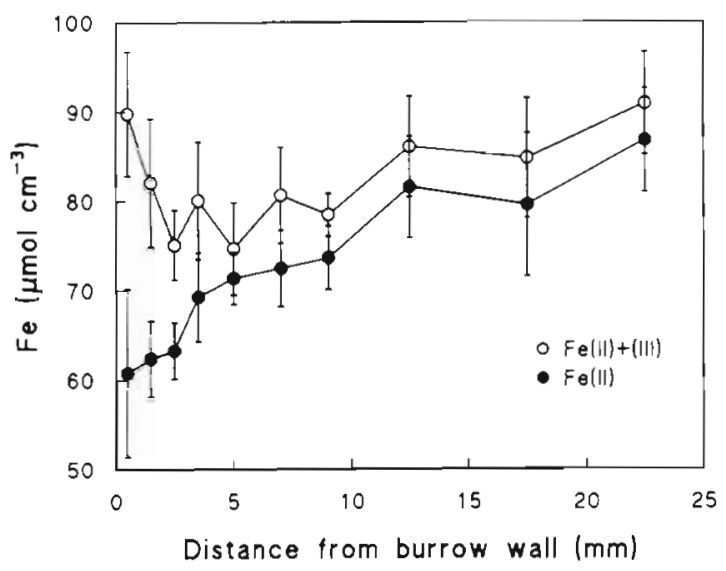

Fig. 8. Radial profiles of $0.25 \mathrm{M} \mathrm{HCl}$-extractable iron separated into $\mathrm{Fe}(\mathrm{I})+(\mathrm{III})(\mathrm{O})$ and $\mathrm{Fe}(\mathrm{II})(\bullet)$ in sediment surrounding Mya arenaria burrows. Values presented as mean $( \pm \mathrm{SE}$; $\mathrm{n}=3$ )

concentrations by the corresponding sulfate reduction rates) provided a simple estimate of the sulfur dynamics (King et al. 1985). $T_{1}$ increased gradually with distance from the burrow wall (Fig. $7 \mathrm{C}$ ) to values about 2.2 times more rapid in the burrow wall $(0-4 \mathrm{~mm})$ than in ambient (15-25 mm) sediment.

\section{Solid phase iron}

The pool of reduced $\mathrm{HCl}$-extractable particulate iron, Fe(II) $)_{\mathrm{HCl}}$, increased gradually with distance from the burrow wall, and was about 1.3 times higher in ambient $(10-25 \mathrm{~mm}$ ) sediment relative to burrow wall $\left(0-3 \mathrm{~mm}\right.$ ) sediment (Fig. 8). Fe(III) HCl $_{\text {determined as }}$ the difference between the total $\mathrm{HCl}$-extractable $\mathrm{Fe}$ content and $\mathrm{Fe}(\mathrm{II})_{\mathrm{HCl}}$ (illustrated as the area between the 2 profiles in Fig 8), was highest in the innermost zone around burrows $\left(29.0 \mu \mathrm{mol} \mathrm{cm}^{-3}\right)$ and declined rapidly with distance. The total extracted Fe content was only markedly different from the Fe(II $)_{\mathrm{HCl}}$-ex- trations for individual samples. However, means of all the data indicatc that SRR and TRS are inversely related (Fig. 7A \& B). Except for the $0-1 \mathrm{~mm}$ sediment, SRR gradually decreased with distance from the burrow wall (Fig 7A). Average TRS concentrations showed the opposite pattern with radial distance, reaching a 'background' level in the $15-25 \mathrm{~mm}$ sediment about 1.4 times higher than in the burrow wall sediment (Fig 7B) The turnover time ( $T_{t}$ ) of reduced sulfur compounds (dividing the TRS
Table 1. Cell numbers of sulfate-reducing bacteria (SRB) and phosholipid phosphorus concentrations in sediment surrounding Mya arenaria burrows. Enumeration of SRB was made by the most-probable-number (MPN) technique. Phospholipid-phosphorus content was used as an estimate of total microbial biomass. See 'Microbial numbers and biomass' for details

\begin{tabular}{|lcc|}
\hline & $\begin{array}{c}\text { SRB } \\
\text { (cells } \mathrm{cm}^{-3} \text { sediment) }\end{array}$ & $\begin{array}{c}\text { Phospholipid phosphorus } \\
\text { (nmol P g }{ }^{-1} \text { dry wt, } \pm \text { SE) }\end{array}$ \\
\hline $\begin{array}{l}\text { Burrow wall sediment } \\
(0-3 \mathrm{~mm})\end{array}$ & $1.1 \times 10^{8}$ & $149.2 \pm 18.5$ \\
$\begin{array}{c}\text { Ambient sediment } \\
(25-30 \mathrm{~mm})\end{array}$ & $1.1 \times 10^{7}$ & $87.3 \pm 11.0$ \\
\hline
\end{tabular}


tracted $\mathrm{Fe}$ in the innermost $3 \mathrm{~mm}$, indicating that Fe(III) $)_{\text {HCl }}$ was present adjacent to the burrow wall only.

\section{Vicrobial numbers and biomass}

MPN determinations of acetate/formate-utilizing sulfate-reducing bacteria were about a factor of 10 higher in the burrow wall $(0-3 \mathrm{~mm})$ sediment as compared to the ambient ( $25-30 \mathrm{~mm}$ ) sediment (Table 1 ). Total microbial biomass, estimated as the content of phospholipid phosphorus, was 1.7 times greater in the burrow wall $(0-3 \mathrm{~mm})$ than in ambient $(25-30 \mathrm{~mm})$ sediment (Table 1).

\section{Artificial burrow experiment (ABEX)}

\section{General observations}

The sediment cores developed a 6 to $8 \mathrm{~mm}$ thick oxidized brownish zone in the topmost sediment within the first 2 wk of incubation. Below this, the sediment had a greyish-brownish colour down to about $2 \mathrm{~cm}$ depth followed by a reduced, greyish-black appearance in the lower sediment column. There was an irregular transition between oxidized and reduced sediment, with no visual difference between sediment cores with artificial burrows and control cores. In the case of the artificially irrigated burrows, however, there was an extension of the oxidized zone in the center as evidenced by a 1 to $3 \mathrm{~mm}$ thick brownish oxidized layer surrounding the burrows. During sampling for SRR assays, some of the oxidized sediment immediately adjacent to the artificial burrow wall may have been lost. The originally white polyethylene burrow material developed an orange-reddish colour in the course of the experiment, most likely from the precipitation of oxidized iron compounds.

\section{Sulfate reduction and reduced inorganic sulfur}

Irrigation of the artificial burrows had a pronounced impact on both SRR and TRS (Fig. 9). Results from the 4 and $8 \mathrm{~cm}$ depth samples showed the same pattern, and have been combined in the figures. Artificial burrow irrigation suppressed sulfate reduction markedly in sediment surrounding burrows (77.8 to $91.1 \mathrm{nmol}$ $\mathrm{cm}^{-3} \mathrm{~d}^{-1}$ in the $0-6 \mathrm{~mm}$ region), and SRR generally increased with the distance from the burrow wall, in the 15-25 mm region approaching values similar to control cores (Fig. 9A). SRR in control cores averaged $169.3 \pm 6.1$ (SE) $\mathrm{nmol} \mathrm{cm}^{-3} \mathrm{~d}^{-1}$ and was on average a factor of 2 higher than in artificially irrigated cores in
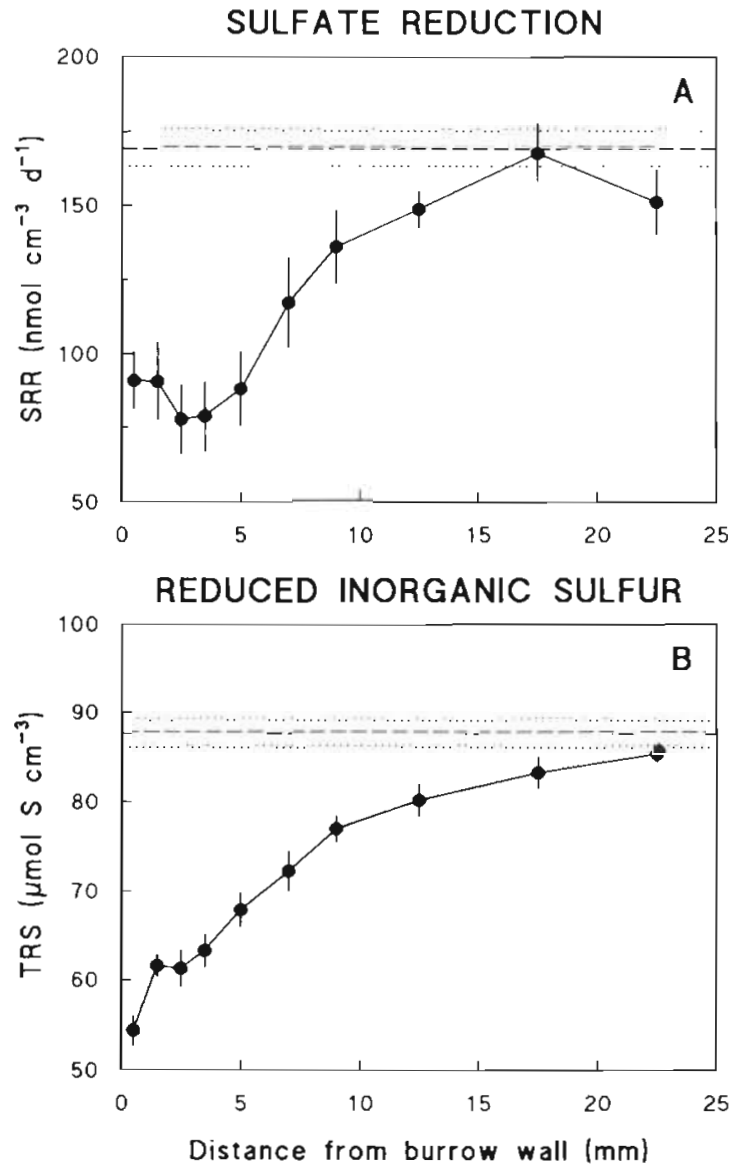

Fig. 9. Artificial burrow experiment (ABEX). Radial profiles of (A) sulfate reduction rates (SRR) and (B) total reduced inorganic sulfur (TRS) in sediment surrounding artificially irrigated burrows. Figures present the average results from the 4 and $8 \mathrm{~cm}$ depth samples (5 samples from each depth) $\pm \mathrm{SE}$ The horizontal dashed ines represent average results from control cores (no burrows) surrounded by SE (dotted lines) Control samples ( 3 from each depth) were each sectioned into five $5 \mathrm{~mm}$ intervals

the $0-6 \mathrm{~mm}$ region. TRS concentrations (Fig. 9B) in artificially irrigated sediment cores increased gradually with distance from the burrow wall, reaching values about 1.5 to 1.6 times higher in the $20-25 \mathrm{~mm}$ interval relative to the $0-1 \mathrm{~mm}$ interval. Concentrations in control cores averaged $87.6 \pm 1.5$ (SE) $\mu \mathrm{mol} \mathrm{S}$ $\mathrm{cm}^{-3}$. TRS concentrations in irrigated cores approached concentrations in the control cores in the 20-25 mm interval.

\section{DISCUSSION}

The rates of sulfate reduction measured in this study lie within ranges previously reported for subtidal and intertidal coastal sediments (e.g. Skyring 1987, Mackin 
\& Swider 1989, Thode-Andersen \& Jørgensen 1989). The vertical profiles of sulfate reduction varied considerably among cores. Previous studies in Lowes Cove (King et al. 1983, King 1990, King unpubl. data) have also shown similar variability with relatively low rates (<100 $\mathrm{nmol} \mathrm{cm}^{-3} \mathrm{~d}^{-1}$ ) in 'bare sediment' (without deposited macroalgae) and relatively high rates $\left(>1000 \mathrm{nmol} \mathrm{cm}^{-3} \mathrm{~d}^{-1}\right)$ in sediment obtained from shallow depressions containing partially buried fragments of macroalgae. Samples from Mya arenaria burrows were obtained more or less randomly from about 5 to $6 \mathrm{~cm}$ depth, and variations in SRR likely reflect general heterogeneity at the site.

Radial profiles of sulfate reduction in the sediment surrounding Mya arenaria burrows changed rather dramatically in the inner 8 to $10 \mathrm{~mm}$, with rates generally 2 to 2.5 times higher than in the ambient sediment. These results indicate that $M$. arenaria enhanced anaerobic microbial activity in its burrow wall sediment. Enhanced SRR is inconsistent with the oxidized appearance of $M$. arenaria burrows and higher oxidized Fe concentrations (Fig. 8). Although the ventilation mechanism of $M$. arenaria is a closed system in which oxygen-rich water is pumped via the inhalent siphon into the mantle cavity and out of the exhalent siphon without directly contacting burrow wall sediment, oxygen may diffuse to the surrounding sediment through the siphon (Pelegrí \& Blackburn 1995). Repeated withdrawals and extensions of the disturbance-sensitive siphons may also enhance the transport of overlying oxygen-rich water to the burrow sediment. Tidally induced water movements may likewise cause alternating drainage and flushing effects of the burrows, which may pull oxygen into the burrow sediment. Of course, oxygen reaching the wall sediment may only penetrate a short distance due to its slow transport and rapid consumption in the burrow wall. Sulfate reduction in oxidized sediments has been explained by the presence of reduced, anaerobic microniches (Jørgensen 1977) Furthermore, different degrees of oxygen tolerance for various species of sulfate-reducing bacteria (SRB) have been demonstrated (e.g Hardy \& Hamilton 1981, Cypionka et al. 1985, Marchall et al. 1993). SRB have also been found to occur in high numbers in oxic sediment (Jorgensen \& Bak 1991), and sulfate reduction has been demonstrated in the presence of oxygen (Canfield \& Des Marais 1991, Fründ \& Cohen 1992, Jørgensen 1994). It should be noted that the presently applied radiotracer method may seriously underestimate the true rate of sulfate reduction in oxic and oxidized burrow wall sediment due to rapid reoxidation of the produced sulfide during incubation (Jorgensen 1994, Moeslund et al. 1994). Contrary to this, part of the oxic zone near the burrow wall may turn anoxic during the incubation
( 4 to $5 \mathrm{~h}$ ), which could lead to an overestimation of SRR compared to natural conditions. The extent of underestimation or overestimation has not been assessed in this study. An additional time course experiment would help to clarify this issue

Decomposition rates of organic matter in marine sediments generally depend upon both the quantity and quality of the organic matter (e.g. Westrich \& Berner 1984. Grant \& Hargrave 1987, Kristensen \& Blackburn 1987. Kristensen \& Hansen 1995). The higher sulfate reduction rates observed in the inner zone surrounding some of the Mya arenaria burrows are presumably the result of increased substrate availability and input of labile organic material, sufficient to offset any inhibitory effects of periodic burrow ventilation. The increased organic content in the burrow walls supports this contention. Likewise, the relatively lower $C: N$ ratios near the burrow wall indicate the presence of more labile, readily degradable microbial organic matter (Kristensen 1990, 1994). Activities by the sessile and more or less stationary $M$. arenaria probably have a limited impact on sediment mixing and translocation of reactive organic matter, as observed for other infau nal groups (Berner \& Westrich 1985, Hines \& Jones 1985)

Infaunal burrow structures are commonly organicrich sites, and often lined with mucus secretions (Aller et al. 1983, Kristensen et al. 1985). Although mucus linings and wall cementation were not evident in $\mathrm{Mya}$ arenaria burrows, a thin layer of mucus secretions may be generated by microbes, meiofauna or $M$. arenaria. Some chemolithotrophic production of organic matter is also probable, as burrow walls are sites for high activity of nitrifiers and sulfide oxidizers (e.g. Aller \& Yingst 1978, Kristensen et al. 1985). Enhanced nitrification has previously been shown in sediment surrounding $M$. arenaria burrows (Henriksen et al. 1983, Pelegrí \& Blackburn 1995, C. Giray \& King unpubl. data). One explanation for the enrichment could also be that the relatively wide burrow openings of $M$. arenaria may act as traps for organic matter and benthic diatoms from above when siphons are retracted.

Excretion of end products of anaerobic metabolism by Mya arenaria might also account for increased sulfate reduction rates. Numerous intertidal bivalves are able to respire anaerobically under conditions of reduced oxygen availability, i.e. during low tide (e.g de Zwaan \& Wijsman 1976, de Zwaan 1977). Accumulation and excretion of various intermediates and end products of anaerobic metabolism have been examined for various bivalves (e.g Kluytmans et al. 1975, de Zwaan \& Wijsman 1976, de Zwaan 1977, Oeschger 1990). Short-chain organic acids, such as lactate, succinate, acetate and propionate, excreted by these bivalves into the surrounding sediment could enhance 
local growth of SRB and sulfate reduction in burrow sediments (Bussmann \& Reichardt 1991). However, further studies are needed to support this hypothesis.

The 2 basic types of sulfate reduction profiles. Type I with maximum rates in the 1 to $5 \mathrm{~mm}$ radial layer and, Type II with highest rates in the 4 to $10 \mathrm{~mm}$ radial region may be attributed to inter-burrow differences in age, sediment structure and composition, and to variations in bivalve ventilation and metabolic activity. Mya arenaria, in the study, site, is harvested commercially and new burrows are constantly being established. Relatively old burrows may be richer in both organic content and microbial populations than newly established burrows. Type II burrows with lowest TRS concentrations in the burrow wall sediment appear more oxidized than Type I burrows. SRR may, therefore, be suppressed in the first mm intervals of Type II burrows, displacing the SRR peak radially away from the burrow wall. It is not clear whether this radial SRR displacement in Type II burrows is due to suppression of SRR in the innermost burrow wall sediment, or whether this is an artifact resulting from sulfide reoxidation in this zone during incubation, or is due to other factors. As noted earlier, the radiotracer assay for SRR may underestimate rates in oxidized burrow wall sediment due to sulfide reoxidation during incubation. Differences in bivalve ventilation activity are likely to influence the extent of oxidation of the burrow sediment. Previous studies (Pedersen 1992) have reported high temporal variation in metabolic activity of $M$. arenaria without any direct relation to the tidal pattern. Thus, the Type II profile may represent burrows inhabited by relatively active clams. In contrast to the pattern for $M$. arenaria burrows, SRR was lowest in sediments adjacent to the artificial burrows. This suggests that the supply of oxygen via irrigation was sufficient to cause a shift in the relative importance of organic matter degradation by SRR. The results further emphasize the potential role of macrofauna in enhancing organic matter availability adjacent to burrows and suggest that substrate enrichment is associated with the activities of $M$. arenaria.

In spite of the variability among samples, TRS concentration profiles indicate that sulfur is lost from the sediment, possibly by oxidation of reduced sulfur species. The increasing turnover time of reduced inorganic sulfur compounds with distance from the burrow wall (Fig. 7C) suggests that Mya arenaria burrows play an important role in the oxidation of sulfides and sulfide removal from the sediment. The profiles of TRS obtained in the artificial burrow experiment similarly indicate loss of sulfides from the sediment surrounding the irrigated burrows. Sulfide oxidation was most likely mediated by the artificial irrigation of oxygenrich water to the otherwise reduced sediment.
Reduced sulfides may be oxidized by various chemical and bacterial processes (Jorgensen 1983, 1988) Besides oxidation by $\mathrm{O}_{2}$ in the oxic sediment, oxidation processes in the anoxic sediment zones may be mediated by nitrate, manganese or iron as electron acceptors (Aller \& Rude 1988, Fossing \& Jørgensen 1990 , King 1990, Elsgaard \& Jørgensen 1992)

Phospholipid phosphorus concentrations indicated that total microbial biomass was elevated in burrow walls of Mya arenaria relative to ambient sediment. The same pattern has been shown for tubes and burrows of other macrofaunal organisms (e.g Aller \& Yingst 1978, 1985, Dobbs \& Guckert 1988). The higher microbial biomass in the innermost burrow wall may also be reflected in the relative lower $C: N$ ratios observed in this zone, which suggest a nitrogen-rich microbial contribution to total sedimentary organic matter. The phospholipid phosphorus concentrations reported here are within the range found by Findlay et al. (1989) for Lowes Cove sediment and by others for a variety of estuarine sediments (e.g. White et al. 1979, Federle et al. 1983). Using a conversion factor $3.43 \times$ $10^{9}$ cells per $100 \mathrm{nmol}$ of phospholipid phosphorus (Findlay et al. 1989), the estimated cell densities in the

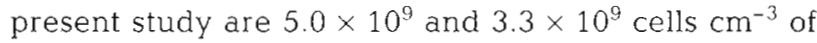
sediment in burrow wall and ambient sediment, respectively. Cell numbers in this range are common for intertidal sediments (e.g. Dale 1974, Rublee 1982 , DeFlaun \& Mayer 1983).

Using a biochemical analysis of phospholipid esterlinked fatty acids (PLFA.), Dobbs \& Guckert (1988) demonstrated higher densities of SRB, such as Desulfobacter spp., in the relatively aerobic burrow lining of Callianassa trilobata, a deep-burrowing thalassinid crustacean, compared to ambient sediment. In the present study MPN results also demonstrated a higher abundance of SRB in burrow wall sediment than in ambient sediment. This pattern corresponded with the distribution of sulfate reduction rates. The numbers of SRB obtained here $\left(1.1 \times 10^{7} \mathrm{~cm}^{-3}\right.$ and $1.1 \times 108 \mathrm{~cm}^{-3}$ in ambient and burrow wall sediment, respectively) are higher than values previously reported on the basis of viable counting techniques $\left(10^{3}\right.$ to $10^{6} \mathrm{~cm}^{-3}$ of sediment, e.g. Jørgensen 1978b, 1983, Hines \& Jones 1985 Gibson et al, 1987, Jørgensen \& Bak 1991, Parkes et al 1993). The estimated specific metabolic rate of SRB in burrow wall ( 0 to $4 \mathrm{~mm}$ ) and ambient (20 to $25 \mathrm{~mm}$ ) sediment was $1.72 \times 10^{-6}$ and $9.27 \times 10^{-6} \mathrm{nmol} \mathrm{SO}_{4}{ }^{2-}$ cell $^{-1} \mathrm{~d}^{-1}$, respectively, which is within the range reported for SRB growing in pure cultures $\left(10^{-6}\right.$ to $10^{-5}$ nmol $\mathrm{SO}_{4}{ }^{2-} \mathrm{cell}^{-1} \mathrm{~d}^{-1}$; Jorgensen 1978b). This suggests that the MPN results in this study provided realistic estimates of true cell numbers.

The present study illustrates the effects of Mya arenaria and its burrows on biogeochemical activities 
related to the sulfur cycle in an intertidal sediment. The results suggest that a zone of elevated sulfur transformations occurs in close proximity to burrow walls. Sulfate reduction rates were up to 2.5 times higher in the inner 1 to $5 \mathrm{~mm}$ region surrounding the burrows, whereas pools of reduced sulfur increased with the distance from burrow walls to values $=1.5$ times higher than in ambient sediment. The radial profiles of SRR indicated that $M$. arenaria burrows typically affect SRR in surrounding sediment within a distance of roughly $8 \mathrm{~mm}$ from the burrow wall, corresponding to $4.5 \mathrm{~cm}^{2}$ of sediment, assuming an average burrow diameter of $10 \mathrm{~mm}$. For typical densities of 200 burrows $\mathrm{m}^{-2}$, about $9 \%$ of the total surface area is affected by $M$. arenaria. Failure to account for enhanced activity in $M$. arenaria burrows could result in an underestimate of SRR by about $15 \%$ relative to bulk sediment rates. If patterns for other macrofauna are similar to those of $M$. arenaria, sulfate reduction near burrow walls may account for a substantial fraction of the total activity. In the ABEX experiment, artificially irrigated burrows suppressed SRR in the innermost zone around burrows, whereas radial profiles of TRS generally resembled those from $M$. arenaria burrows in situ, indicating loss of reduced sulfur compounds from the burrow wall. Substrate enrichment in the burrow wall sediment is most likely responsible for the enhanced SRR around $M$. arenaria burrows. More detailed studies are required to clarify and identify the origin and the mechanisms involved in such substrate enrichment. In addition, the relationship between $M$. arenaria behaviour, e.g. ventilation patterns and metabolic activity, and the patterns and the dynamics of SRR needs greater attention.

Acknowledgements. We thank Sylvia Schnell for help with the MPN assay, and Donald Langworthy for assistance with the phospholipid measurements. We thank Inge Poulsen for the Tefal Jet Line iron. Finally, K.H. thanks the students and staff of the Darling Marine Center for their hospitality. K.H. was supported by the Danish Research Academy; this study was also supported by NSF OCE 9203342

\section{LITERATURE CITED}

Aller JY, Nller RC (1986) Evidence for localized enhancement of biological activity associated with tube and burrow structures in deep-sea sediments at the HEBBLE site, western North Atlantic. Deep Sea Res 33:755-790

Aller RC (1982) The effects of macrobenthos on chemical properties of marine sediment and overlying water. In McCall PL, Tevesz MJS (eds) Animal-sediment relations. Plenum Publ Comp. New York, p 53-102

Aller RC (1988) Benthic fauna and biogeochemical processes in marine sediments. I. The role of burrow structures. In: Blackburn TH, Sørensen J (eds) Nitrogen cycling in coastal marine environments. John Wiley, Chichester. p $301-338$
Aller RC, Rude PD (1988) Complete oxidation of solid phase sulfides by manganese and bacteria in anoxic marine sediments. Geochim Cosmochim Acta 52:751-765

Aller RC, Yingst JY (1978) Biogeochemustry of tubedwellings: a study of the sedentary polychaete Amphitrite ornata (Leidy). J Mar Res 36:201-254

Aller RC, Yingst JY, Ullman WJ (1983) Comparative biogeochemistry of water in intertidal Onuphis (Polychaeta) and Upogebia (Crustacea) burrows: temporal patterns and causes. J Mar Res 41:571-604

Aller RC, Yingst JY (1985) Etfects of the marine depositfeeders Heteromastus filiformis (Polychaeta), Macoma balthica (Bivalvici) and Tellnna texana (Bivalvia) on averaged sedimentar: solute transport, reaction rates, and microbial distributions. J Mar Res 43:615-645

American Public Health Association (1969) Standard methods for the examination of water and wastewater, including bottom sediments and sludge. American Public Health Association, Washington, DC, p 604-609

Andersen $F \varnothing$, Kristensen $E$ (1988) The influence of macrofauna on estuarine benthic community metabolism: a microcosm study. Mar Biol 99:591-603

Andersen $F \varnothing$, Kristensen E (1991) Effects of burrowing macrofauna on organic matter decomposition in coastal marine sediments. Symp Zool Soc Lond 63:69-88

Anderson FE, Black L, Watling LE, Mook W, Mayer LM (1981) A temporal and spatial study of mudflat erosion and deposition. J Sediment Petrol 51:729-736

Bak F, Pfennig $V(1991)$ Sulfate-reducing bacteria ln littoral sediment of Lake Constance. FEMS Microbiol Ecol 85 $43-52$

Berner RA, Westrich JT (1985) Bioturbation and the early diagenesis of carbon and sulfur. Am J Sci 285:193-206

Bussmann I, Reichardt W (1991) Sulfate-reducing bacteria in temporarily oxic sediments with bivalves. Mar Ecol Prog Ser 78:97-102

Canfield DE, Des Marais J (1991) Aerobic sulfate reduction in microbial mats. Science 251:1471-1473

Cline JD (1969) Spectrophotometric determination of hydrogen sulfide in natural waters. Limnol Oceanogr 14: $4.54-458$

Cord-Ruwisch R (1985) A quick method for the determination of dissolved and precipitated sulfides in cultures of sulfate-reducing bacteria. $J$ Microbiol Meth 4:33-36

Cypionka H, Widdel F. Pfennig N (1985) Survival of sulfatereducing bacteria after oxygen stress, and growth in sulfate-free oxygen-sulfide gradients. FEMS Microbiol Ecol $31: 39-45$

Dale NG (1974) Bacteria in intertidal sediments: factors related to their distribution. Limnol Oceanogr 19:509-518

DeFlaun MF, Mayer LM (1983) Relationships between bacteria and grain surfaces in intertidal sediments. Limnol Oceanogr 28:873-881

Dobbs FC, Findlay RH (1993) Analysıs of microbial lipids to determino biomass and detect the response of sedimentary microorganisms to disturbance. In: Kemp PF, Sherr BF, Sherr EB, Cole JJ (eds) Handbook of methods in aquatic microbial ecology. Lewis Publishers, Boca Raton, $p$ $347-358$

Dobbs FC, Guckert JB (1988) Callianassa trilobata (Crustacea: Thalassinideal influences abundance of meiofauna and biomass, composition, and physiologic state of microbial communities within its burrow. Mar Ecol Prog Ser 45: $69-79$

Elsgaard L, Jørgensen BB (1992) Anoxic transformations of radiolabeled hydrogen sulfide in marine and freshwater sediments. Geochim Cosmochim Acta 56:2425-2435 
Emerson CW, Minchinton TE, Grant J (1988) Population structure, biomass, and respiration of Myd arenaria L. on temperate sandflat. J Exp Mar Biol Ecol 115:99-111

Federle TW, Hullar MA, Livingston RJ, Meeter DA, White DC (1983) Spatial distribution of biochemical parameters indicating biomass and community composition of microbiol assemblies in estuarine mud flat sediments. A.ppl Environ Microbiol 45:58-63

Findlay RH, King GM, Watling L (1989) Efficacy of phospholipid analysis in determining microbial biomass in sed.ments. Appl Environ Microbiol 55:2888-2893

Fossing $\mathrm{H}$, Jorgensen BB (1989) Measurement of bacterial sulfate-reduction in sediments: evaluation of a single-step chromium reduction method. Biogeochemistry 8:205-222

Fossing $\mathrm{H}$, Jørgensen BB (1990) Oxidation and reduction of radiolabeled inorganic sulfur compounds in an estuarine sediment, Kysing Fjord, Denmark. Geochim Cosmochim Acta 54:2731-2742

Foster-Smith RL (1978) An analysis of water flow in tube-living animals. J Exp Mar Biol Ecol 34:73-95

Fründ C, Cohen Y (1992) Diurnal cycles of sulfate reduction under oxic conditions in cyanobacterial mats. Appl Environ Microbiol 58:70-77

Gibson GR, Parkes RJ, Herbert RA (1987) Evaluation of viable counting procedures for the enumeration of sulfate-reduc ing bacteria in estuarine sediments. J Microbial Meth 7 $201-210$

Goldhaber MB, Aller RC, Cochran JK, Rosenfeld JK, Martens CS, Berner RA (1977) Sulfate reduction, diffusion, and bioturbation in Long Island Sound sediments: report of the FOAM group. Am J Sci 277:193-237

Grant J, Hargrave BT (1987) Benthic metabolism and the quality of sediment organic carbon. Biol Oceanogr 4: $243-264$

Hardy JA, Hamilton WA (1981) The oxygen tolerance of sulfate-reducing bacteria isolated from North Sea waters. Curr Microbiol 6:259-262

Henriksen K, Rasmussen MB, Jensen A (1983) Effect of bioturbation on microbial nitrogen transformations in the sediment and fluxes of ammonium and nitrate to the overlaying water. Ecol Bull 35:193-205

Hines ME, Jones GE (1985). Microbial biogeochemistry and bioturbation in the sediment of Great Bay. New Hampshire. Estuar Coast Shelf Sci 20:729-742

Jørgensen BB (1977) Bacterial sulfate reduction within reduced microniches of oxidized marine sediments. Mar Biol 41:7-17

Jørgensen BB (1978a) A comparison of methods for the quantification of bacterial sulfate reduction in coastal marine sediments. I. Measurement with radiotracer techniques. Geomicrobiol J 1:11-27

Jørgensen BB (1978b) A comparison of methods for the quantification of bacterial sulfate reduction in coastal marine sediments. III. Estimation from chemical and bacteriological field data. Geomicrobiol J 1:53-68

Jørgensen BB (1982) Mineralization of organic matter in the sea bed-the role of sulphate reduction. Nature 296: 643-645

Jørgensen BB (1983) The microbial sulphur cycle. In: Krumbein WE (ed) Microbial geochemistry. Blackwell Scientific Publications, Alden Press, Oxford, p 91-124

Jørgensen BB (1988) Ecology of the sulphur cycle: oxidative pathways in the sediments. In: Cole JA, Ferguson SJ (eds) The nitrogen and sulphur cycles. Soc Gen Microbiol Symp 42, Cambridge University Press, p 31-63

Jørgensen BB (1994) Sulfate reduction and thiosulfate transformations in a cyanobacterial mat during a diel oxygen cycle. IFMS Microbiol Ecol 13:303-312

Jorgensen BB, Bak F (1991) Pathways and microbiology of thiosulfate transformations and sulfate reduction in a marine sediment (Kattegat, Denmark). Appl Environ Microbiol 57:847-856

Jørgensen BB, Sørensen J (1985) Seasonal cycles of $\mathrm{O}_{2}, \mathrm{NO}_{3}$ and $\mathrm{SO}_{4}{ }^{2-}$ reduction in estuarine sediments: the significance of an $\mathrm{NO}_{3}$ reduction maximum in spring. Mar Ecol Prog Ser 24:65-74

Jorgensen CB, Riisgàrd HL (1988) Gill pump characteristics of the soft clam Mya arenaria. Mar Biol 99:107-109

King GM (1990) Effects of added manganic and ferric oxides on sulfate reduction and sulfide oxidation in intertidal sediments. FEMS Microbiol Ecol 73:131-138

King GM, Howes BL, Dacey JWH (1985) Short-term endproducts of sulfate reduction in a salt marsh: formation of acid volatile sulfides, elemental sulfur, and pyrite. Geochim Cosmochim Acta 49:1561-1566

King GM, Klug MJ, Lovley DR (1983) Metabolism of acetate, methanol, and methylated amines in intertidal sediments of Lowes Cove, Maine. Appl Environ Microbiol 45: $1848-1853$

Kluytmans JH, Veenhof PR, Zwaan A de (1975) Anaerobic production of volatile fatty acids in the sea mussel Mytilus edulis L. J Comp Physiol 104:71-78

Kristensen E (1988) Benthic fauna and biogeochemical processes in marine sediments: microbial activities and fluxes. In: Blackburn TH, Sørensen J (eds) Nitrogen cycling in coastal marine environments. John Wiley, Chichester, p 275-299

Kristensen E (1990) Characterization of biogemc organic matter by stepwise thermogravimetry (STG). Biogeochemistry 9:135-159

Kristensen E (1994) Decomposition of macroalgae, vascular plants and sediment detritus in seawater: use of stepwise thermogravimetry. Biogeochemistry 26:1-24

Kristensen E, Andersen FO (1987) Determination of organic carbon in marine sediments: a comparison of two CHNanalyzer methods. J Exp Mar Biol Ecol 109:15-23

Kristensen E, Blackburn TH (1987) The fate of organic carbon and nitrogen in experimental marine sediment systems influence of bioturbation and anoxia. J Mar Res 45: $231-257$

Kristensen E, Hansen K (1995) Decay of plant detritus in organic-poor marine sediment: production rates and stoichiometry of dissolved $\mathrm{C}$ and $\mathrm{N}$ compounds. $J$ Mar Res 53:675-702

Kristensen E, Jensen MH, Andersen TK (1985) The impact of polychaete (Nereis virens Sars) burrows on nitrification and nitrate reduction in estuarine sediments. J Exp Mar Biol Ecol 85:75-91

Lovley DR, Phillips EJP (1987) Rapid assay for microbially reducible ferric iron in aquatic sediments. Appl Environ Microbiol 53:1536-1540

Mackin JE, Swider KT (1989) Organic matter decomposition pathways and oxygen consumption in coastal marine sediments. J Mar Res 47:681-716

Marschall C, Frenzel P, Cypionka H (1993) Influence of oxygen on sulfate reduction and growth of sulfate-reducing bacteria. Arch Microbiol 159:168-173

Moeslund L. Thamdrup B, Jørgensen BB (1994) Sulfur and iron cycling in a coastal sediment: radiotracer studies and seasonal dynamics. Biogeochemistry 27:129-152

Nichols FH (1985) Increased benthic grazing: an alternative explanation for low phytoplankton biomass in Northern San Francisco Bay during the 1976-1977 drought. Estuar Coast Shelf Sci 21:379-388 
Oeschger $\mathrm{R}$ (1990) Long-term anaerobiosis in sublittoral marine invertebrates from the Western Baltic Sea: Halicryptus spinulosus (Priapulida), Astarte borealis and Arctica lslandica (Bivalvia). Mar Ecol Prog Ser 5y:133-143

Parkes RJ, Dowlıng NJE, White DC, Herbert RA, Gibson GR (1993) Characterization of sulphate-reducing bacterial populations within marine and estuarine sediments with different rates of sulphate reduction. FEMS Microbiol Ecol 102:235-250

Pedersen TF (1992) Temporal variations in heat dissipation and oxygen uptake of the soft shell clam Mya arenaria L. (Bivalvia). Ophelia 36:203-216

Pelegri SP, Blackburn TH (1995) Effect of bioturbation by Neress sp., Mya arenaria and Cerastoderma sp. on nitrification and denitrification in estuarine sediments. Ophelia 42:289- 299

Reichardt W (1988) Impact of bioturbation by Arenicola marina on microbiological parameters in intertidal sediments. Mar Ecol Prog Ser 44:149-158

Rhoads DC (1974) Organism-sediment relations on the muddy sea floor. Oceanogr Mar Biol 12:263-300

Rice DL (1986) Early diagenesis in bioadvective sediments: relationships between the diagenesis of beryllium-7, sediment reworking rates, and the abundance of conveyor-belt deposit-feeders. J Mar Res 44:149-184.

Rublee PA (1982) Bacterial and microbial distribution in estuarine sediments. In: Kennedy $\mathrm{V}$ (ed) Estuarine comparisons. Academic Press, New York, p 159-182

Skyring GW (1987) Sulfate reduction in coastal ecosystems. Geomicrobiol J 5:295-374

Sørensen J, Jørgensen BB, Revsbech NP (1979) A comparison of oxygen, nitrate, and sulfate respiration in coastal marine sediments. Microb Ecol 5:1.05-115

Responsible Subject Editor: T H. Blackburn, Aarhus, Denmark
Tabatabai MA (1974) Determination of sulfate in water samples. Sulphur Inst J 10:11-13

Thode-Andersen S, Jorgensen BB (1989) Sulfate reduction and the tormation of ${ }^{35} \mathrm{~S}$-labeled FeS, $\mathrm{FeS}_{2}$ and $S_{01}$ in coastal marine sediments. Limnol Oceanogr 34:793-806

Westrich JT, Berner RA (1984) The role of sedimentary organic matter in bacterial sulfate reduction: the $\mathrm{G}$ model tested. Limnol Oceanogr 29:236-249

White DC, Davis WM, Nickels JS, King JD, Bobbie RJ (1979) Determination of the sedimentary microbial biomass by extractible lipid phosphate. Oecologia 40:51-62

Widdel F (1986) Growth of methanogenic bacteria in pure culture with 2-propanol and other alcohols as hydrogen donors. Appl Environ Microbiol 51:1056-1062

Widdel F, Bak F (1991) Gram-negative mesophilic sulfatereducing bacteria. In: Balows $A$, Trüper $H G$, Dworkın $M$, Harder W, Schleifer $\mathrm{KH}$ (eds) The procaryotes, 2 nd edn. Vol 4. Springer-Verlag, New York, p 3352-3378

Widdel $F$, Pfennig $N$ (1981) Studies on dissimilatory sulfatereducing bacteria that decompose fatty acids. I. Isolation of new sulfate-reducing bacteria enriched with acetate from saline environments. Description of Desulfobacter postgatei gen. nov., sp. nov. Arch Microbiol 129:395-400

Yingst JY, Rhoads DC (1980) The role of bioturbation in the enhancement of bacterial growth rates in marine sediments. In: Tenore KL, Coull BC (eds) Marine benthic dynamics. University of South Carolina Press, Columbia, p 421

Zwaan A de (1977) Anaerobic energy metabolism in bivalve molluscs. Oceanogr Mar Biol A Rev 15:103-187

Zwaan A de, Wijsman TCM (1976) Anaerobic metabolism in Bivalvia (Mollusca). Characteristics of anaerobic metabo]ısm. Comp Biochem Physiol 54:313-324

Manuscript first received: October 10, 1995

Revised version accepted: January 1, 1996 